\title{
GERMINATION AND EARLY GROWTH OF PHYSIC NUT SUBMITTED TO LEVELS OF SALINITY
}

\section{LUIZ A. LIMA ${ }^{1}$, WILLIAN F. DE ALMEIDA ${ }^{2}$, PEDRO L. T. LIMA ${ }^{3}$, EDUARDO C. OLIVEIRA $^{4}$, CLINTON C. SHOCK $^{5}$}

\begin{abstract}
Two experiments were conducted to evaluate the effect of salinity on early physic nut plant development. In the first trial, physic nut seeds were exposed to seven levels of salinity $(0$, $2,4,6,8,10$ and $12 \mathrm{dS} \mathrm{m}^{-1}$ ) with eight repetitions, using a substrate of paper soaked with solutions of $\mathrm{CaCl}_{2}$ and $\mathrm{KCl}$. The treatments were evaluated based on the initial germination, total percentage of germination, and time necessary to germination of $50 \%$ of the seeds. Increased salinity reduced the first germination count and delayed the time to $50 \%$ germination. From $10 \mathrm{dS} \mathrm{m} \mathrm{m}^{-1}$, there was a reduction in germination percentage. The second trial evaluated the effect of salinity on the growth of physic nut seeds. This trial, carried out inside a greenhouse, with a completely randomized design, was composed of five salinity treatments $\left(0.02,2,4,6\right.$ and $\left.8 \mathrm{dS} \mathrm{m} \mathrm{m}^{-1}\right)$ with 5 replications. It was observed that salinity levels above $2 \mathrm{dS} \mathrm{m}^{-1}$ affected plant development. The current study suggests that salinity management is an important factor to be considered to achieve the potential productivity of physic nut.
\end{abstract}

KEYWORDS: Jatropha curcas L., seeds, seedlings, greenhouse.

\section{GERMINAÇÃO E DESENVOLVIMENTO INICIAL DO PINHÃO-MANSO SUBMETIDO A NÍVEIS DE SALINIDADE}

RESUMO: Foram realizados dois experimentos para avaliar o efeito da salinidade sobre o desenvolvimento inicial do pinhão-manso. No primeiro ensaio, sementes de pinhão-manso foram expostas a sete níveis de salinidade $\left(0 ; 2 ; 4 ; 6 ; 8 ; 10\right.$ e $\left.12 \mathrm{dS} \mathrm{m}^{-1}\right)$, com oito repetições, utilizando substrato de papel umedecido com soluções de $\mathrm{CaCl}_{2}$ e $\mathrm{KCl}$. Os tratamentos foram avaliados com base na germinação inicial, porcentagem de germinação total e tempo necessário para germinação de $50 \%$ das sementes. O aumento da salinidade reduziu a primeira contagem de germinação e retardou o tempo para $50 \%$ de germinação. A partir de $10 \mathrm{dS} \mathrm{m}^{-1}$, houve redução na porcentagem de germinação. O segundo ensaio avaliou o efeito da salinidade no crescimento de mudas de pinhão-manso. Este, conduzido em casa de vegetação, com delineamento inteiramente causualizado, foi composto de cinco tratamentos de salinidade $\left(0,02 ; 2 ; 4 ; 6\right.$ e $\left.8 \mathrm{dS} \mathrm{m}^{-1}\right)$, com 5 repetições. Observou-se que a salinidade acima de $2 \mathrm{dS} \mathrm{m}^{-1}$ afetou o desenvolvimento das plantas. A presente pesquisa sugere que o manejo da salinidade é um importante fator a ser considerado para a obtenção da produtividade potencial do pinhão-manso.

PALAVRAS-CHAVE: Jatropha curcas L., sementes, mudas, ambiente protegido.

\section{INTRODUCTION}

Due to the intensive search for alternative fuels to petroleum, such as biodiesel, there were several researches using potential oilseeds to produce green fuel, especially physic nut, a plant with high yield potential and wide edaphoclimatic adaptation. Jatropha curcas L. is a species of the Euphorbiaceae family found in almost all intertropical regions of the planet, and South and Central Americas are the most likely origin center. It is a plant known for its high oil content in its seeds,

\footnotetext{
${ }^{1}$ Eng $^{\circ}$. Agrícola, Prof. Ph.D, Departamento de Engenharia, (DEG/UFLA).

${ }^{2} \mathrm{Tecg}^{\mathrm{o}}$ em Recursos Hídricos /Irrigação, Pós-doutorando Engenharia Agrícola, UFLA.

${ }^{3}$ Eng $^{\circ}$. Agrícola, M.Sc. Recursos Hídricos em Sistemas Agrícolas, Doutorando em Ciência do Solo, UFLA.

${ }^{4}$ Eng $^{\circ}$ Agrícola, Doutor em Recursos Hídricos em Sistemas Agrícolas, UFLA.

${ }^{5} \mathrm{Ph}$. D, Director and Professor Oregon State University Malheur Experiment Station.

Recebido pelo Conselho Editorial em: 14-5-2012
}

Aprovado pelo Conselho Editorial em: 24-5-2013 
besides being a perennial species, demanding in insolation and apparently tolerant to drought, pests and diseases (TOMINAGA et al., 2007; ACHTEN et al., 2008). This plant, according to DAS et al. (2009), adapts well to semi-arid regions, and has high productivity.

Regarding irrigation, EVANGELISTA et al. (2011) evaluated the productivity of physic nut and observed positive effects of irrigation and of the application of organo-mineral fertilizers. SOUSA et al. (2011) observed an increase of the oil content of the seeds of physic nut with hydric replacement.

Semi-arid regions are characterized by having insufficient water and poorly distributed rains, physically and temporally. These regions may suffer problems of salinization, since leaching and transportation of soluble salts are restricted due to low rainfall and high rates of evaporation. This process is usually accelerated by poorly sized irrigation and deficient draining (BORGES JÚNIOR \& ANDRADE, 2008).

According to PARIDA \& DAS (2005), soil or water salinity is one of the main abiotic stresses, which severely limits the growth and yield of plants. Salinization reduces the plant ability to absorb water, due to reduced osmotic potential of the soil solution, and also induces the nutritional imbalance, due to the high ionic concentration and toxicity of some ions (MUNNS, 2002).

The plants responses to salt stress may vary, depending on their sensitivity or tolerance. Some common symptoms are chlorosis, burns on the edges of leaves, and rickets, among others. MUNNS (2002) reports that the tolerance of a culture to salinity may vary both between genotypes of the same species such as the stage of development. The detection of plants physiological changes associated with salinity is essential to avoid major losses in culture productivity. Several studies report the negative effect of salinity on the productivity of various cultures and their economic and ecological importance (BLANCO et al., 2007; CHEN et al., 2010; ISLA \& ARAGÜÉS, 2010; MALASH et al., 2010).

Recently, there was great concern of researchers in Brazil and around the world to evaluate the behavior of physic nut subjected to salt stress. Some of these studies were conducted in the same period of the present research, however they were all performed with $\mathrm{NaCl}$ salt (GAO et al., 2008; NERY et al., 2009; ANDRÉO-SOUZA et al., 2010; KUMAR et al., 2010; PATEL et al. 2010).

In the present research, carried out with $\mathrm{CaCl}_{2}$ and $\mathrm{KCl}$ salts, we aimed to evaluate, by means of two experiments, the effect of salinity on the germination of seeds of physic nut and evaluate the initial development of seedlings when subjected to different levels of salinity of irrigation water.

\section{MATERIAL AND METHODS}

Two experiments were conducted at the Federal University of Lavras (UFLA), located in Lavras city - state of Minas Gerais (MG), in Brazil, located in the geographical coordinates $21^{\circ} 13.8^{\prime}$ South latitude and $44^{\circ} 58.5^{\prime}$ 'West longitude, at an average altitude of $905 \mathrm{~m}$.

Experiment I: The objective was to evaluate the effect of salinity on seed germination of physic nut. It was conducted at the Seed Analysis Laboratory of the Department of Agriculture of UFLA. The physic nut seeds were subjected seven levels of salinity $\left(0,2,4,6,8,10\right.$ and $\left.12 \mathrm{dS} \mathrm{m}^{-1}\right)$.

A saline solution was prepared, with an electrical conductivity higher than the highest treatment, with a mixture of calcium chloride and potassium chloride salts at a ratio of 22.3:1 $\mathrm{CaCl}_{2}: \mathrm{KCl}$ maintaining a ratio of $15: 1 \mathrm{Ca}: \mathrm{K}$ This solution was diluted in water to prepare the electrical conductivity levels desired for the experiment. Although electrical conductivity is a reliable parameter to estimate the salinity of the soil solution, the electrical conductivity of the soil itself is still questionable, as quoted by MOLIN \& RABELLO (2011).

The experimental design was completely randomized with eight replications. The experimental unit consisted of germitest paper roll with 25 seeds of physic nut. 
Following the methodology recommended by BRASIL (1992), 25 seeds were distributed on two sheets of germitest paper, properly moistened with the saline solution of each treatment, in a volume equivalent to 2.5 times the weight of the dry paper. Then, a third sheet of paper was placed on the seeds, and the assembly was folded and tied at the upper and lower ends, forming rolls, and thus the plot was characterized. Then, the eight rolls, corresponding to the replicates, were grouped by treatment with two more sheets, one involving the rolls and another on top; this ensemble was placed in a germinator of Mangelsdorf type in an upright position to germinate. Observations were made daily, after insertion into the germinator, during 14 days.

On the 5th day, time of the first count, the seeds with roots, with satisfactory development, were eliminated; procedure adopted until the end of the observations. This information allowed us to evaluate the percentage of seed germination in the first count and the total percentage of germination during the observed period.

We evaluated the following parameters: total percentage of germination, first count of germination, and time to protrusion of $50 \%$ of the seeds.

The obtained results were submitted to analysis of variance, and the "F" test was used to evaluate the significance levels. Means were compared by TUKEY test at 5\% probability. Analyzes of linear and quadratic regression were also made, choosing to evaluate the results the one that best correlated with the data.

Experiment II: In order to evaluate the effect of salinity on the early development of seedlings of physic nut, this experiment was conducted in a greenhouse of the Department of Engineering of UFLA. Seedlings of physic nut with 30 days of age were used, transplanted in pots with a volume of 21 liters.

The soil (Distroferric Red Latosol) used in the experiment was collected at UFLA (LavrasMG) at a depth of 0-30 cm, whose granulometric analysis showed mean values of $68 \mathrm{dag} \mathrm{kg}^{-1}$ of clay, $22 \mathrm{dag} \mathrm{kg}^{-1}$ of silt, and $10 \mathrm{dag} \mathrm{kg}^{-1}$ of sand.

The values of the soil chemical properties, found before fertilization of the seedlings planting, obtained according to EMBRAPA (1997), are presented in Table 1. The fertilization was performed according to the recommendations to castor bean contained in RIBEIRO et al. (1999). This procedure was adopted because so far there are not specific fertilizer recommendations for growing physic nut, and because it is a culture of the same family of castor bean. There was no need for liming.

TABLE 1. Chemical characteristics of the soil before fertilization.

\begin{tabular}{|c|c|c|c|c|c|c|c|c|c|c|c|c|c|c|}
\hline $\mathrm{pH}$ & O.M. & $\mathrm{P}$ & $\mathrm{Ca}$ & $\mathrm{Mg}$ & $\mathrm{H}+\mathrm{Al}$ & SB & CTC & V & $\mathrm{K}$ & B & $\mathrm{Cu}$ & $\mathrm{Fe}$ & $\mathrm{Mn}$ & $\mathrm{Zn}$ \\
\hline & $\mathrm{g} \mathrm{dm}^{-3}$ & $\mathrm{mg} \mathrm{dm}_{3}^{-}$ & --- & & --mmo & $\mathrm{dm}^{-3}$ & & $\%$ & & & & & & \\
\hline 6.1 & 13 & 1.4 & 13 & 1.0 & 17 & 14 & 31 & 45.9 & 16 & 0.1 & 3.3 & 58.4 & 11.8 & 0.3 \\
\hline
\end{tabular}

The statistical design used was completely randomized with five treatments and five replications, the portion consisting of a plant/pot, totaling 25 pots. The experimental plots were spaced at $1.00 \mathrm{~m} \times 0.60 \mathrm{~m}$. The treatments consisted of five salinity levels of irrigation water $(\mathrm{N})$, obtained by dilution of water of electrical conductivity $10.10 \mathrm{dS} \mathrm{m} \mathrm{m}^{-1}\left(334.5 \mathrm{~g} \mathrm{of} \mathrm{CaCl}_{2}\right.$, and $15 \mathrm{~g}$ of $\mathrm{KCl}$ diluted in 50 liters of water) to obtain levels of $0.02 ; 2 ; 4 ; 6$; and $8 \mathrm{dS} \mathrm{m}^{-1}$ at $25^{\circ} \mathrm{C}$. Treatments were irrigated based on the characteristic curve of the soil (Equation 1), aiming to keep the soil at field capacity.

$$
\theta=0.244+\left(\frac{0.657-0.244}{\left.[1+(0.244] \Psi T)^{2.784}\right]^{0.6245}}\right)
$$


In which:

$\theta=$ moisture content based on volume $\left(\mathrm{cm}^{3} \mathrm{~cm}^{-3}\right)$;

$\Psi=$ potential of water in the soil $(\mathrm{kPa})$.

For this, we used blocks of electrical resistance (Watermark Soil Moisture Sensors Model 200SS, Irrometer Co. Inc., Riverside Calif., USA), installed at $0.15 \mathrm{~m}$ depth, near the plant, in the central region of the pot. The water replacement was performed when the mean water tension in the soil reached $20 \mathrm{kPa}$, being reduced to $10 \mathrm{kPa}$ (SHOCK, 2003). The control of pests and diseases was done by weekly sprays using acaricide based on sulfur and fungicides.

A digital thermo- hygrometer was installed inside the greenhouse to measure temperature and relative air humidity. Measurements were performed daily always at 16 o'clock.

The variables plant height, stem diameter and number of leaves were measured at 14, 28, 42, 56, 70, 84, 98, 112, 126, 140 and 146 days after transplanting (DAT), and the variables leaf area, fresh mass and dry mass of stem and leaves were measured at the end of the experiment. Data were subjected to analysis of variance, means were compared by Tukey test at $5 \%$ probability and polynomial regression, using SISVAR statistical software (FERREIRA, 2008).

\section{RESULTS AND DISCUSSION}

\section{Experiment I}

There were significant effects $(P<0.01)$ of salinity levels on the total percentage of germination, first count of germination and time to $50 \%$ germination (Table 1).

There was a $29 \%$ reduction in total percentage of germination when comparing N7 $\left(12 \mathrm{dS} \mathrm{m}{ }^{-1}\right)$ with $\mathrm{N} 1\left(0 \mathrm{dS} \mathrm{m}{ }^{-1}\right)$ (Table 3). It is observed that there were significant difference only in the levels of 10 and $12 \mathrm{dS} \mathrm{m} \mathrm{m}^{-1}$. ANDRÉO-SOUZA et al. (2010) also found a significant reduction in the percentage of germination of physic nut seeds in concentrations of 10 and $12 \mathrm{dS} \mathrm{m}^{-1}$, performing the same test, but with the $\mathrm{NaCl}$ salt.

Through regression curve (Figure 1), we notice that the total percentage of germination had a small increase in estimated level of $2 \mathrm{dS} \mathrm{m}^{-1}$, and then decreases slowly, a fact also observed by ANDRÉO-SOUZA et al. (2010).

PATEL et al. (2010), when studying the salinity stress in physic nut seeds in the soil, obtained a germination percentage of $82 \%$ in the control $\left(0.3 \mathrm{dS} \mathrm{m} \mathrm{m}^{-1}\right)$ and reported a $76 \%$ reduction in salinity of $3.9 \mathrm{dS} \mathrm{m}^{-1}$ to $5 \%$ in salinity of $10 \mathrm{dS} \mathrm{m} \mathrm{m}^{-1}$, proving that this level of salinity is detrimental to the germination of physic nut.

TABLE 2. Summary of Analysis of Variance (ANOVA) for germination percentage (GP), first count of germination (FCG) and the time to occurrence of $50 \%$ of germination (T50) of physic nut in salinity levels.

\begin{tabular}{lccc}
\hline Cause of Variance & GP & FCG & T50 \\
\hline & & Test F \\
Salinity & $14,45^{* *}$ & $74,02^{* *}$ & $46,088^{* *}$ \\
Linear Pol. Reg. & $67,69^{* *}$ & $431,191^{* *}$ & $271,945^{* *}$ \\
Quadratic Pol. Reg. & $16,80^{* *}$ & $7,527^{* *}$ & $0,84^{\mathrm{ns}}$ \\
Q. M. Residue & 50,61 & 67,43 & 0,0905 \\
CV $(\%)$ & 8,72 & 17,58 & 7,37 \\
\hline
\end{tabular}

** Significant at $1 \%$ probability level; ns - not significant; Pol. Reg. - Polynomial Regression 
TABLE 3. Mean data for total percentage of germination (TPG), first count of germination (FCG) and the time to occurrence of $50 \%$ of germination (T50) of seeds of physic nut in salinity levels (electrical conductivity).

\begin{tabular}{ccccc}
\hline Level & Salinity (dS/m) & PG (\%) & FCG (\%) & T50 (days) \\
\hline N1 & 0 & $88.0 \mathrm{ab}$ & $82.0 \mathrm{a}$ & $3.14 \mathrm{a}$ \\
N2 & 2 & $90.0 \mathrm{a}$ & $74.5 \mathrm{a}$ & $3.34 \mathrm{a}$ \\
N3 & 4 & $87.5 \mathrm{ab}$ & $56.5 \mathrm{~b}$ & $3.81 \mathrm{~b}$ \\
N4 & 6 & $85.0 \mathrm{ab}$ & $41.5 \mathrm{c}$ & $4.10 \mathrm{bc}$ \\
N5 & 8 & $81.5 \mathrm{ab}$ & $30.5 \mathrm{~cd}$ & $4.33 \mathrm{~cd}$ \\
N6 & 10 & $76.5 \mathrm{~b}$ & $24.0 \mathrm{~d}$ & $4.62 \mathrm{~d}$ \\
N7 & 12 & $61.0 \mathrm{c}$ & $18.0 \mathrm{~d}$ & $5.21 \mathrm{e}$ \\
\hline
\end{tabular}

Means followed by the same letter in the column do not differ by Tukey test at 5\% probability.

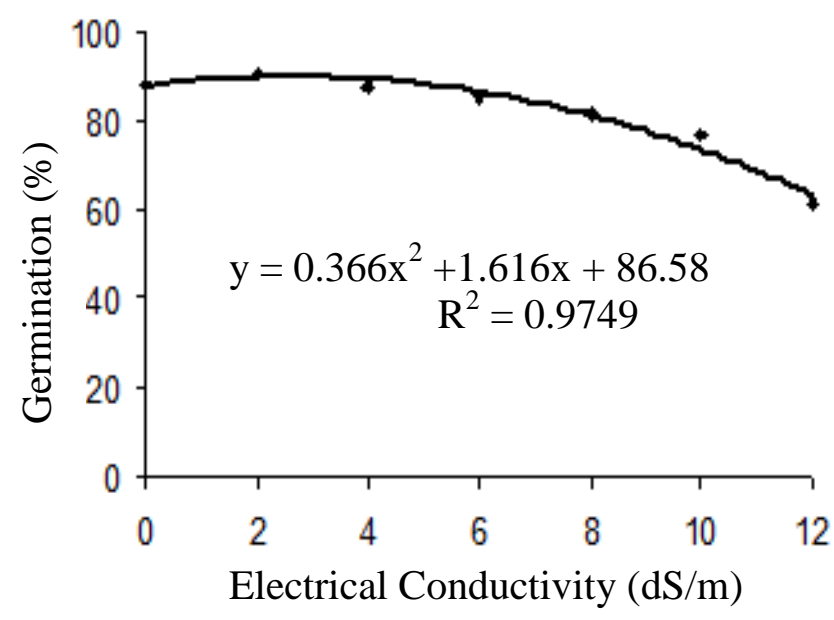

FIGURE 1. Total percentage of germination of seedlings of physic nut as a function of salinity levels. Adjusted model: $\mathrm{y}=\mathrm{b}_{2} \mathrm{x}^{2}+\mathrm{b}_{1} \mathrm{x}+\mathrm{b}_{0}$ with significance levels by $\mathrm{t}$ test of the coefficients of the regression: b2 (1\%), b1 (5\%).

Regarding the first count of germination, it was found by the regression curve (Figure 2) a marked reduction, with the increase in electrical conductivity.

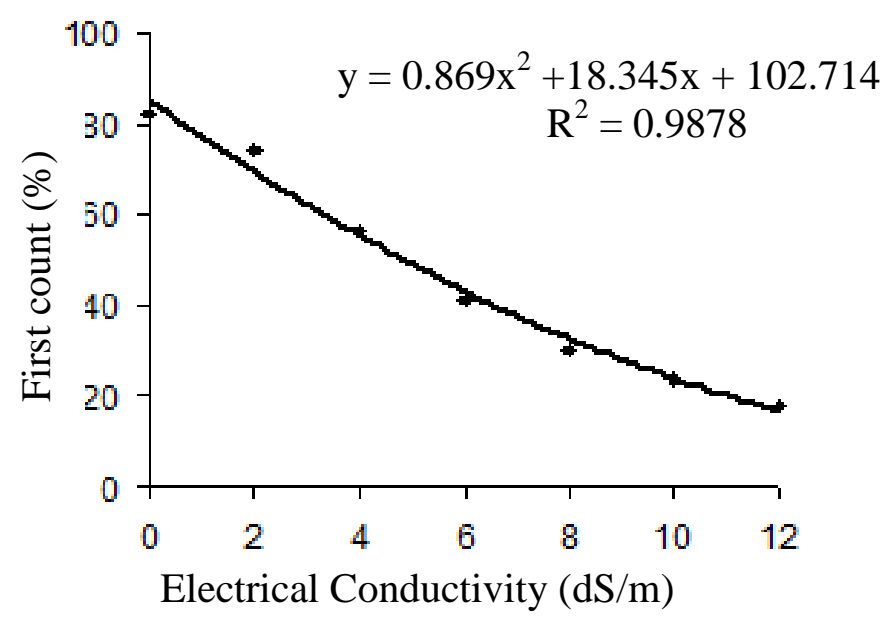

FIGURE 2. Percentage of germination of physic nut seedlings in the first count as a function of salinity levels. Adjusted model: $\mathrm{y}=\mathrm{b}_{2} \mathrm{x}^{2}+\mathrm{b}_{1} \mathrm{x}+\mathrm{b}_{0}$ with significance levels by t test of the coefficients of the regression: $\mathrm{b} 1$ and $\mathrm{b} 2(1 \%)$.

Comparing the data at the end of germination and the first count, it was found that germination progresses as the time progresses between the first and last reading, having good 
germination in most of the salinity levels at the end. This can be possibly attributed to the characteristics of the culture to overcome the osmotic potential to which it was submitted, which makes more evident the salts toxic effect to seeds. According to HADAS (1976), the enzyme activity is delayed with decreasing external water potential and causes delay in meristem development and in emergence of radicle.

Regarding the time to occurrence of $50 \%$ of germination, we found an adjustment to linear regression model linear behavior, with increase in the number of days, so $50 \%$ of the seeds germinate, as the electrical conductivity increased. The smaller the number of days to reach T50, the faster is the germination and the greater if the plant growth potential (Figure 3). Thus, it is possible to check that the higher the salinity, the greater are the damages to germination, and hence the rate of emission of seedlings is impaired.

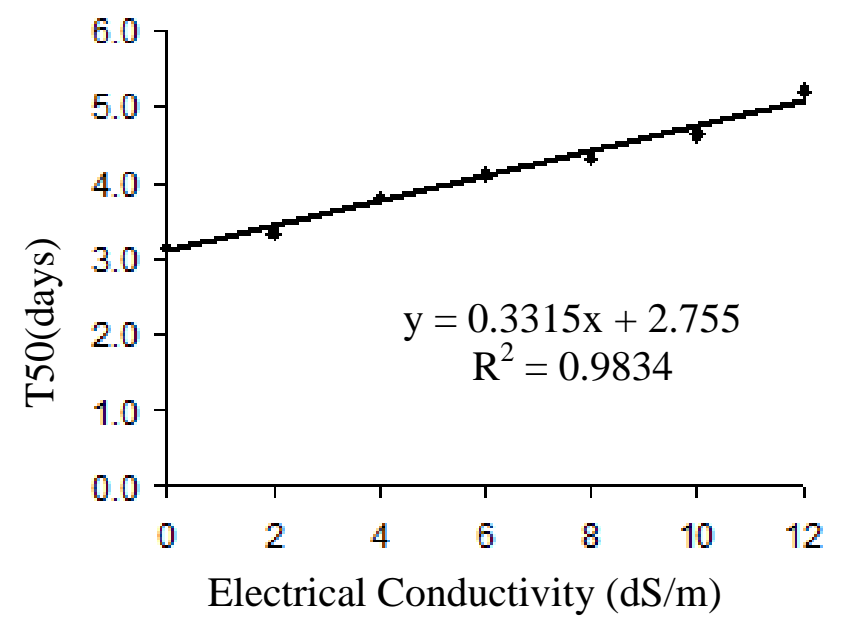

FIGURE 3. Time required for $50 \%$ of germination of physic nut seeds as a function of salinity levels. Adjusted model: $y=b_{1} x+b_{0}$ with significance levels by t test of the regression coefficient: b1 (1\%).

PATEL et al. (2010) also found delay in seedling emergence with the increase of salinity. According to the authors, the increase in salinity reduces the osmotic potential of soil water and consequently the availability of soil water to plants, damaging germination and seedling development.

\section{Experiment II}

It was observed inside the greenhouse, during the experiment, mean, maximum and minimum temperatures of $25.9^{\circ} \mathrm{C}, 41.6^{\circ} \mathrm{C}$ and $6.6^{\circ} \mathrm{C}$, respectively, and the average of the maximum and minimum was $33.4^{\circ} \mathrm{C}$ and $18.4^{\circ} \mathrm{C}$. The values of mean, maximum and minimum humidity were $63.7 \%, 94 \%$ and $19 \%$, and the average of the maximum and minimum was $85.5 \%$ and $41.9 \%$, respectively.

Plant height for each level of salinity is shown in Figure 4. It is observed that the heights, for different salinities of water, began to distance during the studied period, and we may observe the influence of salinity levels over time.

Plant height had a linear behavior for the levels $0.02,2$ and $4 \mathrm{dS} \mathrm{m} \mathrm{m}^{-1}$ and a quadratic behavior for the levels 6 and $8 \mathrm{dS} \mathrm{m} \mathrm{m}^{-1}$, showing that the two higher levels were more harmful to plant growth (Figure 4 and Table 4).

It is also observed that the rate of plant growth is initially lower until 42 DAT, with incremental increases from 56 to $126 \mathrm{DAT}$, and then with diminishing increases in the last two evaluations (140 and 146 DAT). This lower final growth rate, as well as the short interval between evaluations, are due to climate factor, because in cooler days the physic nut goes dormant and 
consequently it decreases its growth, also occurring natural loss of leaves as reported by SATURNINO et al. (2005).

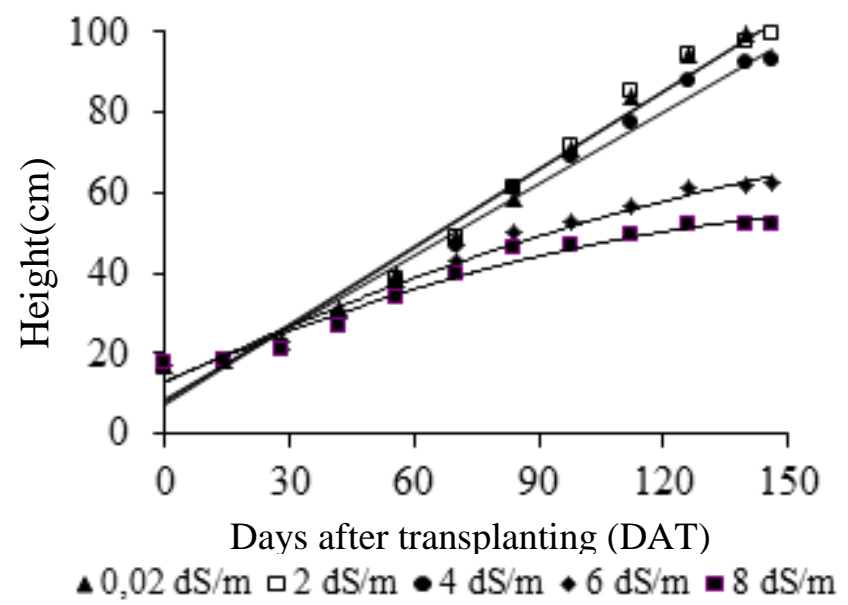

FIGURE 4. Plant height $(\mathrm{cm})$ as a function of days after transplanting (DAT), and regression curves for salinity levels.

TABLE 4. Regression equations for plant height $(\mathrm{PH}, \mathrm{cm})$ as a function of days after transplanting (DAT) for salinity.

\begin{tabular}{cccc}
\hline Levels & $\begin{array}{c}\text { Salinity } \\
(\mathbf{d S} / \mathbf{m})\end{array}$ & Equations & $\mathbf{R}^{\mathbf{2}}$ \\
\hline $\mathrm{N} 1$ & 0.02 & $\mathrm{PH}=0.645 \mathrm{DAT}^{* *}+8.08$ & 0.98 \\
$\mathrm{~N} 2$ & 2 & $\mathrm{PH}=0.647 \mathrm{DAT}^{* *}+7.47$ & 0.98 \\
$\mathrm{~N} 3$ & 4 & $\mathrm{PH}=0.597 \mathrm{DAT}^{* *}+8.45$ & 0.98 \\
$\mathrm{~N} 4$ & 6 & $\mathrm{PH}=-0.0009 \mathrm{DAT}^{2 * *}+0.489 \mathrm{DAT}^{* *}+12.81$ & 0.98 \\
$\mathrm{~N} 5$ & 8 & $\mathrm{PH}=-0.0012 \mathrm{DAT}^{2 * *}+0.455 \mathrm{DAT}^{* *}+13.01$ & 0.97 \\
\hline
\end{tabular}

Adjusted models: $y=b_{1} x+b_{0} ; y=b_{2} x^{2}+b_{1} x+b_{0}$, significance levels of the regression coefficients, ** significant at $1 \%$ probability, respectively, by t test.

According to BRITO \& ANDRADE (2010), the limitation of the culture growth occurs because of the need to spend more energy to absorb water from the soil, due to the decrease in osmotic component of the water potential of the soil with the increase of salinity.

In castor bean, crop in the same family of physic nut, it was also observed decreases with increasing salinity (SILVA et al., 2008). The authors observed decreases of $62.92 \%$ relative to the level of $6.7 \mathrm{dS} \mathrm{m}^{-1}$ compared to the level of $0.7 \mathrm{dS} / \mathrm{m}$, with considerable reductions of the height from $4.7 \mathrm{dS} \mathrm{m} \mathrm{m}^{-1}$.

NERY et al. (2009), also working with physic nut, verified at 163 days after sowing, linear reduction of plant height, with decreases of $3.78 \%$ per unit increase of electrical conductivity of irrigation water $(\mathrm{NaCl})$ in the greenhouse.

Stem diameter was affected by salinity over time (Figure 5). We observe a decrease with increasing salinity, and the levels 4,6 and $8 \mathrm{dS} \mathrm{m}^{-1}$ were the most damaging to this variable. 


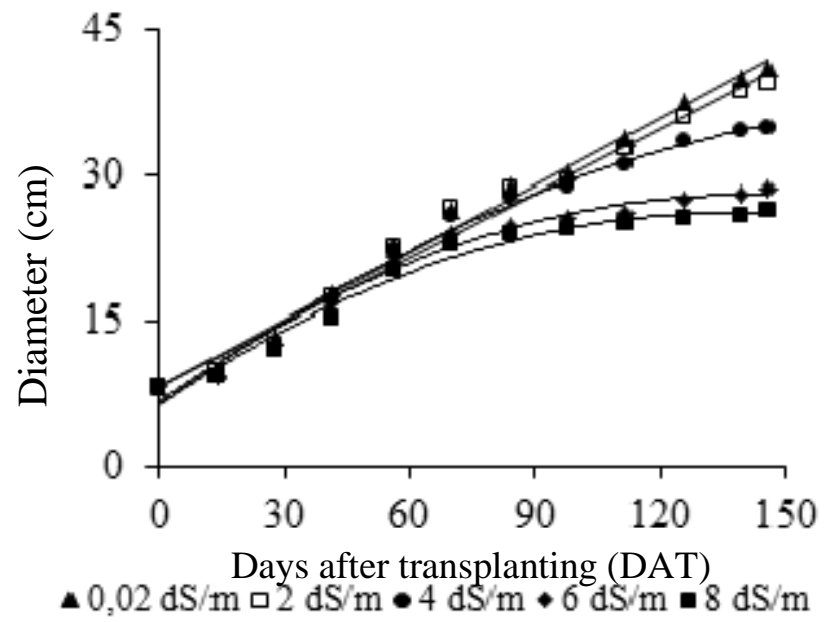

FIGURE 5. Stem diameter $(\mathrm{mm})$ as a function of days after transplanting (DAT), and regression curves for salinity levels.

TABLE 5. Regression equations for stem diameter $(\mathrm{D}, \mathrm{mm})$ as a function of days after transplanting (DAT) for salinity levels.

\begin{tabular}{|c|c|c|c|}
\hline Levels & $\begin{array}{c}\text { Salinity } \\
\text { (dS/m) }\end{array}$ & Equations & $\mathbf{R}^{2}$ \\
\hline N1 & 0.02 & $\mathrm{D}=0.233 \mathrm{DAT}^{* *}+8.01$ & 0.99 \\
\hline $\mathrm{N} 2$ & 2 & $\mathrm{D}=0.223 \mathrm{DAT}^{* *}+8.15$ & 0.98 \\
\hline N3 & 4 & $\mathrm{D}=-0.0008 \mathrm{DAT}^{2 * *}+0.315 \mathrm{DAT}^{* *}+6.178$ & 0.98 \\
\hline N4 & 6 & $\mathrm{D}=-0.0011 \mathrm{DAT}^{2 * *}+0.308 \mathrm{DAT}^{* *}+6.49$ & 0.98 \\
\hline N5 & 8 & $\mathrm{D}=-0.001 \mathrm{DAT}^{2 * *}+0.291 \mathrm{DAT}^{* *}+6.24$ & 0.97 \\
\hline
\end{tabular}

Adjusted models: $y=b_{1} x+b_{0} ; y=b_{2} x^{2}+b_{1} x+b_{0}$, significance levels of the regression coefficients, $* *$ significant at $1 \%$ probability, respectively, by $t$ test.

Reductions in stem diameter of physic nut were also verified by NERY et al. (2009), where they found that this variable was sensitive to salinity from $2.4 \mathrm{dS} \mathrm{m} \mathrm{m}^{-1}$.

SILVA et al. (2009) found that stem diameter of physic nut decreased by $50 \%$ at the highest dose of $\mathrm{NaCl}(100 \mathrm{mM})$ when compared to control plants.

The number of plant leaves was linear for levels $0.02,2.0$ and $4.0 \mathrm{dS} \mathrm{m}^{-1}$, and the levels 2 and $4 \mathrm{dS} \mathrm{m} \mathrm{m}^{-1}$ were higher than $0.02 \mathrm{dS} \mathrm{m}^{-1}$; whereas the levels 6 and $8 \mathrm{dS} \mathrm{m} \mathrm{m}^{-1}$ had a quadratic behavior with considerable decrease in the number of leaves (Figure 6 and Table 6).

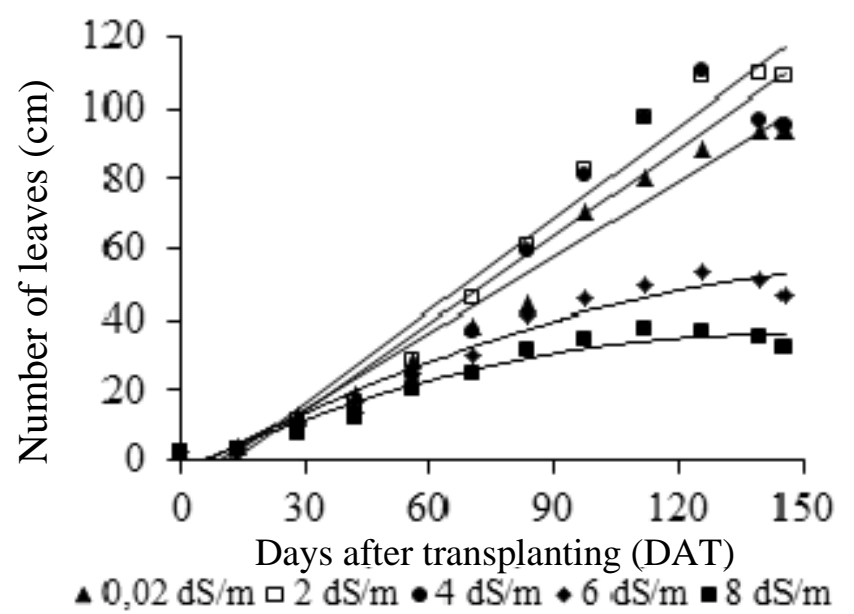

FIGURE 6. Number of leaves as a function of days after transplanting (DAT), and regression curves for salinity levels. 
TABLE 6. Regression equations for the number of leaves (NL) as a function of days after transplanting (DAT) for salinity levels.

\begin{tabular}{cccc}
\hline Levels & $\begin{array}{c}\text { Salinity } \\
(\mathbf{d S} / \mathbf{m})\end{array}$ & Equations & $\mathbf{R}^{\mathbf{2}}$ \\
\hline $\mathrm{N} 1$ & 0.02 & $\mathrm{NL}=0.712 \mathrm{DAT}^{* *}-6.42$ & 0.97 \\
$\mathrm{~N} 2$ & 2 & $\mathrm{NL}=0.868 \mathrm{DAT}^{* *}-10.05$ & 0.96 \\
N3 & 4 & $\mathrm{NL}=0.818 \mathrm{DAT}^{* *}-10.14$ & 0.92 \\
N4 & 6 & $\mathrm{NL}=-0.0017 \mathrm{DAT}^{2 * *}+0.637 \mathrm{DAT}^{* *}-4.05$ & 0.95 \\
$\mathrm{~N} 5$ & 8 & $\mathrm{NL}=-0.001873 \mathrm{DAT}^{2 * *}+0.539032 \mathrm{DAT}^{* *}-2.888$ & 0.95 \\
\hline
\end{tabular}

Adjusted models: $y=b_{1} x+b_{0} ; y=b_{2} x^{2}+b_{1} x+b_{0}$, significance levels of the regression coefficients, ** significant at $1 \%$ probability, respectively, by t test.

It is observed in Figure 6 that the levels of salinity 2 and $4 \mathrm{dS} \mathrm{m} \mathrm{m}^{-1}$ had a positive effect on the number of leaves, being even a little higher than the level without salts $\left(0.02 \mathrm{dS} \mathrm{m}^{-1}\right)$, i.e., salinity of irrigation water increased the number of leaves per plant, which was not observed in the levels 6 and $8 \mathrm{dS} \mathrm{m} \mathrm{m}^{-1}$. The probable reason of such an event may be the application of the nutrients potassium and calcium present in the salts used for salinization of irrigation water. However, as can be seen below, the leaf area of the level $4 \mathrm{dS} \mathrm{m}^{-1}$ is lower than the one of $0.02 \mathrm{dS} \mathrm{m}^{-1}$.

It can be seen from Table 7 that the leaf area was significantly affected by the increase of salinity of irrigation water. It can be observed that the greater value of leaf area was obtained with a salinity level of $2 \mathrm{dS} \mathrm{m}^{-1}$, which is probably due to the presence of calcium and potassium applied through irrigation water. Above the level of $2 \mathrm{dS} \mathrm{m}^{-1}$, there was a marked decrease in this variable.

TABLE 7. Summary of Analysis of Variance (ANOVA) and means for leaf area of physic nut in different levels of salinity.

\begin{tabular}{ll}
\hline Cause of Variance & Leaf Area \\
\hline & F Test \\
\cline { 2 - 2 } Salinity & $259.002^{* *}$ \\
Linear Pol. Reg. & $863.686^{* *}$ \\
Quadratic Pol. Reg. & $27.894^{* *}$ \\
\hline Q. M. Residue & 222006.59 \\
CV $(\%)$ & 9.14 \\
\hline Salinity & Means $\left(\mathrm{cm}^{2}\right)$ \\
$\mathrm{N}_{1}\left(0.02 \mathrm{dS} \mathrm{m}^{-1}\right)$ & $7621.09 \mathrm{~b}$ \\
$\left.\mathrm{~N}_{2}(2 \mathrm{dS} \mathrm{m})^{-1}\right)$ & $9190.53 \mathrm{a}$ \\
$\mathrm{N}_{3}\left(4 \mathrm{dS} \mathrm{m} \mathrm{m}^{-1}\right)$ & $5463.67 \mathrm{c}$ \\
$\mathrm{N}_{4}\left(6 \mathrm{dS} \mathrm{m} \mathrm{m}^{-1}\right)$ & $2112.80 \mathrm{~d}$ \\
$\mathrm{~N}_{5}\left(8 \mathrm{dS} \mathrm{m} \mathrm{m}^{-1}\right)$ & $1375.75 \mathrm{~d}$ \\
\hline
\end{tabular}

** Significant at $1 \%$ probability level. Means followed by the same uppercase or lowercase letter do not differ by Tukey test $(p<$ 0.05). Pol. Reg. - Polynomial Regression

Evaluating cotton under saline conditions ( 0.50 to $\left.8.50 \mathrm{dS} \mathrm{m}^{-1}\right)$, OLIVEIRA et al. (2008) found that the salinity of irrigation water affected significantly the leaf area. When working with physic nut, NERY et al. (2009) found a reduction of $17.74 \%$ per unit increase of electrical conductivity of irrigation water.

According to TESTER \& DAVENPORT (2003), this decrease in leaf area is possibly related to one of the mechanisms of plant adaptation to salt stress, decreasing the transpiring surface.

In Table 8 we may see the summary of the analysis of variance for fresh and dry mass of the stem and leaves as a function of the salinity levels of irrigation water. It is noted that the factor of salinity of irrigation water had a significant effect $(p<0.01)$ for all variables. According to NERY 
et al. (2009), to understand the behavior of the growth of the shoot area of culture is of great importance, since this feature is an indicator of salt stress in physic nut.

TABLE 8. Summary of ANOVA for fresh mass of leaves (FML), dry mass of leaves (DML), fresh mass of stem (FMS) and dry mass of stem (DMS).

\begin{tabular}{cccccc}
\hline \multirow{2}{*}{ Factor of Variation } & \multirow{2}{*}{ G.L. } & \multicolumn{4}{c}{ Q.M } \\
\cline { 3 - 6 } & & FML & DML & FMS & DMS \\
\hline Salinity & 4 & $35736.5^{* *}$ & $1594.0^{* *}$ & $293121.5^{* *}$ & $36071.5^{* *}$ \\
Residue & 20 & 146.5 & 10.5 & 1791.0 & 844.0 \\
\hline Mean & & 133.6 & 38.4 & 427.6 & 150.6 \\
CV $(\%)$ & & 9.06 & 8.44 & 9.90 & 19.29 \\
\hline
\end{tabular}

** Significant at $1 \%$ probability level by $\mathrm{F}$ test.

Analyzing Figure 7, it can be seen that the characteristics of fresh mass of leaves, dry mass of leaves, fresh mass of stem, and dry mass of stem were affected by salinity of irrigation water. It is observed that these characteristics had the same behavior as the leaf area, with marked decrease when the salinity level was higher than $2 \mathrm{dS} \mathrm{m}^{-1}$.

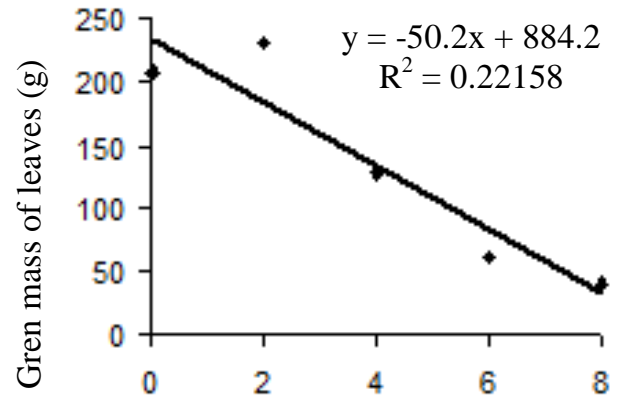

Electrical Conductivity $(\mathrm{dS} / \mathrm{m})$

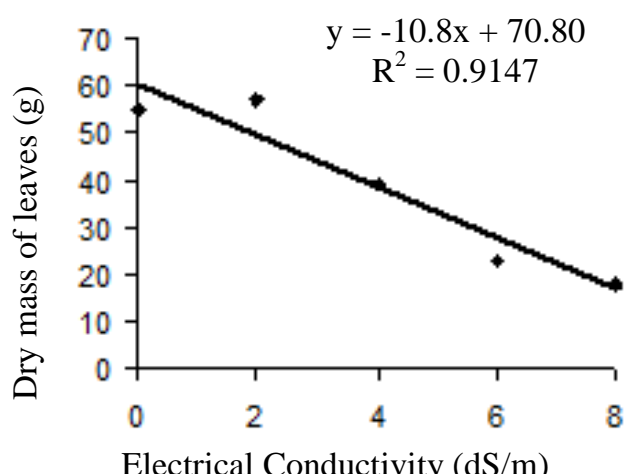

Electrical Conductivity $(\mathrm{dS} / \mathrm{m})$

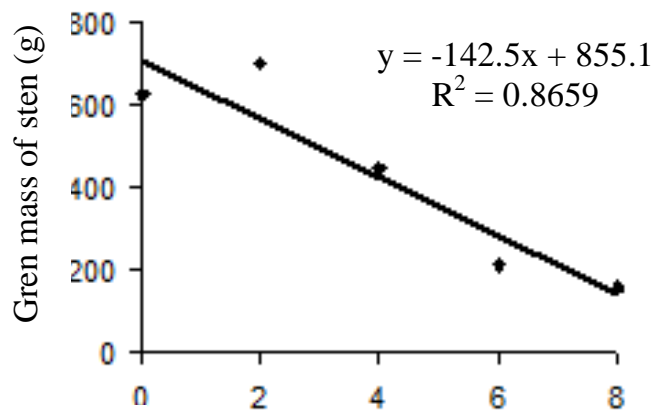

Electrical Conductivity $(\mathrm{dS} / \mathrm{m})$

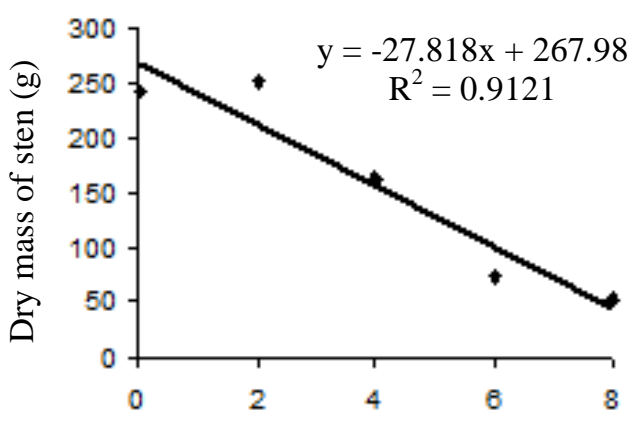

Electrical Conductivity (dS/m)

FIGURE 7. Regression curves of the characteristics green mass of leaves, dry mass of leaves, green mass of stem and dry mass of stem in relation to salinity levels at 146 days after transplanting. Adjusted model: $\mathrm{y}=\mathrm{b}_{1} \mathrm{x}+\mathrm{b}_{0}$ with significance levels by $\mathrm{t}$ test of the regression coefficient: b1 (1\%).

SILVA et al. (2009) and OLIVEIRA et al. (2010) also found the negative effect of salinity on the dry mass of physic nut with the increase of salinity. Drastic reduction in dry mass of shoot area of Jatropha curcas L., according to the increase of salt concentration in the soil, was also observed by PATEL et al. (2010), who also found a significant reduction in plant height and leaf area. 


\section{CONCLUSIONS}

1. The percentage of germination of physic nut is affected when the salinity level is greater than $10 \mathrm{dS} \mathrm{m} \mathrm{m}^{-1}$. The first count of germination is significantly reduced with increasing salinity and the time to $50 \%$ of germination increases with increasing salinity.

2. In relation to development, salinity levels cause reduction in vegetative variables, and the initial growth of physic nut is significantly impaired when the salinity is greater than $2 \mathrm{dS} \mathrm{m}^{-1}$.

3. The management of salinity is an important factor to be considered to achieve the potential productivity of physic nut.

\section{REFERENCES}

ACHTEN, W.M.J.; VERCHOT, L.; FRANKEN, Y.J.; MATHIJS, E.; SINGH, V.P.; AERTS, R.; MUYS, B. Jatropha bio-diesel production and use. Biomass and Bioenergy, Oxford, v.32, n.12, p. 1063-1084, 2008.

ANDRÉO-SOUZA, Y.; PEREIRA, A. L.; SILVA, F. F. S.; RIEBEIRO-REIS, R. C.;

EVANGELISTA, M. R. V.; CASTRO, R. D.; DANTAS, B. F. Efeito da salinidade na germinação de sementes e no crescimento inicial de mudas de pinhão-manso. Revista Brasileira de Sementes, Viçosa-MG, v.32, n.2, p.83-92, 2010.

BLANCO, F. F.; FOLEGATTI, M. V.; GHEYI, H. R. FERNANDES, P. D.. Emergence and growth of corn and soybean under saline stress. Scientia Agricola, Piracicaba, v.64, n.5, p.451-459, 2007.

BORGES JÚNIOR, J.C.F.; ANDRADE, C.L.T. Transporte de solutos no solo. In:

ALBUQUERQUE, P.E.P.; DURÃES, F.O.M. (Ed.). Uso e manejo da irrigação. Brasília: Embrapa Informação Tecnológica, 2008. p.151-168.

BRASIL, Ministério da Agricultura e Reforma Agrária. Regras para análise de sementes. Brasília: SNDA/DNDV/CLAV, 1992.365p.

BRITO, R.A.L.; ANDRADE, C.L.T. Qualidade da água na agricultura e no meio ambiente. Informe Agropecuário, Belo Horizonte, v.31, n.259, p.50-57, 2010.

CHEN, W.; HOU, Z.; WU, L.; LIANG, Y.; WEI, C. Effects of salinity and nitrogen on cotton growth in arid environment. Plant and Soil, The Hague, v.326, n.1-2, p. 61-73, 2010.

DAS S.; LAPOLA, D.; PRIESSJ.A. Estimating the potential of Jatropha curcas as a biofuel crop in South India using simulation results from two crop models. IOP Conference Series: Earth and Environmental Science, v. 6, n. 18, 2009.

EMBRAPA. EMPRESA BRASILEIRA DE PESQUISA AGROPECUÁRIA. Manual de métodos de análise de solo. Rio de Janeiro: Embrapa-CNPS, 1997. 212 p. (Documentos, 1).

EVANGELISTA, A.W.P.; MELO, P.C.; OLIVEIRA, E.L.; FARIA, M.A. Produtividade e rendimento de sementes de pinhão manso submetido à irrigação e adubação com OMM-Tech. Engenharia Agrícola, Jaboticabal, v.31, n.2, p.315-323, 2011.

FERREIRA, D.F. SISVAR: um programa para análises e ensino de estatística. Revista Científica Symposium, Lavras, v.6, p.36-41, 2008.

GAO, S.; OUYANG, C.; WANG, S.; XU, Y.; TANG, L.; CHEN F. Effects of salt stress on growth, antioxidant enzyme and phenylalanine ammonia-lyase activities in Jatropha curcas L. seedlings. Plant Soil Environmental, v.54, p.374-381, 2008.

HADAS, A. Water uptake and germination of leguminous seeds under changing external water potential in osmotic solutions. Journal of Experimental Botany, Oxford, v.27, n.98, p.480-489, 1976. 
ISLA, R.; ARAGÜÉS, R. Yield and plant ion concentrations in maize (Zea mays L.) subject to diurnal and nocturnal saline sprinkler irrigations. Field Crops Research, Amsterdam, v.116, n.1-2, p.175-183, 2010.

KUMAR, A.; SHARMA, S.; MISHRA, S. Influence of arbuscular mycorrhizal (AM) fungi and salinity on seedling growth, solute accumulation, and mycorrhizal dependency of Jatropha curcas L. Journal of Plant Growth Regulation, New York, v.29, p.297-306, 2010.

MALASH, N. M.; FLOWERS, T. J.; RAGAB, R. Effect of irrigation methods, management and salinity of irrigation water on tomato yield, soil moisture and salinity distribution. Irrigation Science, New York, v.26, n.4, p. 313-323, 2010.

MOLIN, J.P.; RABELLO, L.M. Estudos sobre a mensuração da condutividade elétrica do solo. Engenharia Agrícola, Jaboticabal, v.31, n.1, p.90-101, 2011.

MUNNS, R. Comparative physiology of salt and water stress. Plant Cell and Environment, Oxford, v.25, n.2, p. 239-250, 2002.

NERY, A. R.; RODRIGUES, L. N.; SILVA, M. B. R.; FERNANDES, P. D.; CHAVES, L. H. G.; DANTAS NETO, J.; GHEYI, H. R. Crescimento do pinhão-manso irrigado com águas salinas em ambiente protegido. Revista Brasileira de Engenharia Agrícola e Ambiental, Campina Grande, v.13, n.5, p.551-558, 2009.

OLIVEIRA, A. M.; OLIVEIRA, A.M.P.; DIAS, N.S.; MEDEIROS, J.F. Irrigação com água salina no crescimento inicial de três cultivares de algodão. Irriga, Botucatu, v.13, n.4, p.467-475, 2008.

OLIVEIRA, I. R.S.; OLIVEIRA, F. N.; MEDEIROS, M. A.; TORRES, S. B.; TEIXEIRA, F. J. V. Crescimento inicial do pinhão-manso (Jatropha curcasL.) em função da salinidade da água de irrigação. Caatinga, Mossoró, v.23, n.4, p.40-45, 2010.

PARIDA A. K.; DAS A.B. Salt tolerance and salinity effect on plants: a review. Ecotoxicology and Environmental Safety, New York, v.60, p.324-349, 2005.

PATEL, A. D.; PANCHAL, N. S.; PANDEY, I. B.; PANDEY, A. N. Growth, water status and nutrient accumulation of seedlings of Jatropha curcas L. (Euphorbiaceae) in response to soil salinity. Anales de Biología, Murcia, v.32, p.59-71, 2010.

RIBEIRO, A. C.; GUIMARÃES, P. T. G.; ALVAREZ, V. V. H. Recomendação para uso de corretivos e fertilizantes em Minas Gerais: $5^{\text {a }}$ aproximação. Viçosa: Comissão de Fertilidade do Solo do Estado de Minas Gerais, 1999. 359 p.

SATURNINO, H.M.; PACHECO, D.D.; KAKIDA, J.; NAGASHI, T.; GONÇALVES, N.P. Cultura do pinhão-manso (Jatropha curcas L.). Informe Agropecuário, Belo Horizonte, v.26, n.229, p.4478, 2005.

SHOCK, C.C. Soil water potential measurement by granular matrix sensors. In: STEWART, B.A.; HOWELL, T.A. (Ed.). The Encyclopedia of water science. Marcel Dekker, 2003. p 899-903.

SOUSA, A.E.C.; GHEYI, H.R.; SOARES, F.A.L.; MEDEIROS, E.P.; NASCIMENTO, E.C.S. Teor de óleo no pinhão manso em função de lâminas de água residuária. Pesquisa Agropecuária Brasileira, Rio de Janeiro, v.46, n.1, 2011.

SILVA, S. M. S.; ALVES, A. N.; GHEYI, H. R.; BELTRÃO, N. E.; SEVERINO, L. S.; SOARES, F. A. L. Desenvolvimento e produção de duas cultivares de mamoneira sob estresse salino. Revista Brasileira de Engenharia Agrícola e Ambiental, Campina Grande, v.12, n.4, p. 335-342, 2008.

SILVA, E. N.; SILVEIRA, J. A. G.; FERNANDES, C. R. R.; DUTRA, A. T. B.; ARAGÃO, R. M. Acúmulo de íons e crescimento de pinhão-manso sob diferentes níveis de salinidade. Revista Ciência Agronômica, Fortaleza, v.40, n.2, p. 240-246, 2009. 
TESTER, M.; DAVENPORT, R. Na ${ }^{+}$tolerance and $\mathrm{Na}^{+}$transport in higher plants. Annals of Botany, London, v.91, n.5, p. 503-527, 2003.

TOMINAGA, N.; KAKIDA, J.; YASUDA, E.K.; SOUSA, L.A.; RESENDE, P.L.; SILVA, N.D.; Cultivo de pinhão-manso para produção de biodiesel: manual. Viçosa, MG: CPT, 2007. 220 p.

ISLA, R.; ARAGÜÉS, R. Yield and plant ion concentrations in maize (Zea mays L.) subject to diurnal and nocturnal saline sprinkler irrigations. Field Crops Research, Amsterdam, v.116, n.1-2, p.175-183, 2010.

KUMAR, A.; SHARMA, S.; MISHRA, S. Influence of arbuscular mycorrhizal (AM) fungi and salinity on seedling growth, solute accumulation, and mycorrhizal dependency of Jatropha curcas L. Journal of Plant Growth Regulation, New York, v.29, p.297-306, 2010.

MALASH, N. M.; FLOWERS, T. J.; RAGAB, R. Effect of irrigation methods, management and salinity of irrigation water on tomato yield, soil moisture and salinity distribution. Irrigation Science, New York, v.26, n.4, p. 313-323, 2010.

MOLIN, J.P.; RABELLO, L.M. Estudos sobre a mensuração da condutividade elétrica do solo. Engenharia Agrícola, Jaboticabal, v.31, n.1, p.90-101, 2011.

MUNNS, R. Comparative physiology of salt and water stress. Plant Cell and Environment, Oxford, v.25, n.2, p. 239-250, 2002.

NERY, A. R.; RODRIGUES, L. N.; SILVA, M. B. R.; FERNANDES, P. D.; CHAVES, L. H. G.; DANTAS NETO, J.; GHEYI, H. R. Crescimento do pinhão-manso irrigado com águas salinas em ambiente protegido. Revista Brasileira de Engenharia Agrícola e Ambiental, Campina Grande, v.13, n.5, p.551-558, 2009.

OLIVEIRA, A. M.; OLIVEIRA, A.M.P.; DIAS, N.S.; MEDEIROS, J.F. Irrigação com água salina no crescimento inicial de três cultivares de algodão. Irriga, Botucatu, v.13, n.4, p.467-475, 2008.

OLIVEIRA, I. R.S.; OLIVEIRA, F. N.; MEDEIROS, M. A.; TORRES, S. B.; TEIXEIRA, F. J. V. Crescimento inicial do pinhão-manso (Jatropha curcasL.) em função da salinidade da água de irrigação. Caatinga, Mossoró, v.23, n.4, p.40-45, 2010.

PARIDA A. K.; DAS A.B. Salt tolerance and salinity effect on plants: a review. Ecotoxicology and Environmental Safety, New York, v.60, p.324-349, 2005.

PATEL, A. D.; PANCHAL, N. S.; PANDEY, I. B.; PANDEY, A. N. Growth, water status and nutrient accumulation of seedlings of Jatropha curcas L. (Euphorbiaceae) in response to soil salinity. Anales de Biología, Murcia, v.32, p.59-71, 2010.

RIBEIRO, A. C.; GUIMARÃES, P. T. G.; ALVAREZ, V. V. H. Recomendação para uso de corretivos e fertilizantes em Minas Gerais: $5^{\mathrm{a}}$ aproximação. Viçosa: Comissão de Fertilidade do Solo do Estado de Minas Gerais, 1999. 359 p.

SATURNINO, H.M.; PACHECO, D.D.; KAKIDA, J.; NAGASHI, T.; GONÇALVES, N.P. Cultura do pinhão-manso (Jatropha curcas L.). Informe Agropecuário, Belo Horizonte, v.26, n.229, p.44$78,2005$.

SHOCK, C.C. Soil water potential measurement by granular matrix sensors. In: STEWART, B.A.; HOWELL, T.A. (Ed.). The Encyclopedia of water science. Marcel Dekker, 2003. p 899-903.

SOUSA, A.E.C.; GHEYI, H.R.; SOARES, F.A.L.; MEDEIROS, E.P.; NASCIMENTO, E.C.S. Teor de óleo no pinhão manso em função de lâminas de água residuária. Pesquisa Agropecuária Brasileira, Rio de Janeiro, v.46, n.1, 2011.

SILVA, S. M. S.; ALVES, A. N.; GHEYI, H. R.; BELTRÃO, N. E.; SEVERINO, L. S.; SOARES, F. A. L. Desenvolvimento e produção de duas cultivares de mamoneira sob estresse salino. Revista Brasileira de Engenharia Agrícola e Ambiental, Campina Grande, v.12, n.4, p. 335-342, 2008. 
SILVA, E. N.; SILVEIRA, J. A. G.; FERNANDES, C. R. R.; DUTRA, A. T. B.; ARAGÃO, R. M. Acúmulo de íons e crescimento de pinhão-manso sob diferentes níveis de salinidade. Revista Ciência Agronômica, Fortaleza, v.40, n.2, p. 240-246, 2009.

TESTER, M.; DAVENPORT, R. $\mathrm{Na}^{+}$tolerance and $\mathrm{Na}^{+}$transport in higher plants. Annals of Botany, London, v.91, n.5, p. 503-527, 2003.

TOMINAGA, N.; KAKIDA, J.; YASUDA, E.K.; SOUSA, L.A.; RESENDE, P.L.; SILVA, N.D.; Cultivo de pinhão-manso para produção de biodiesel: manual. Viçosa, MG: CPT, 2007. 220 p. 